\title{
Child Marriage and the Failure of INTERNATIONAL LAW: A COMPARISON OF AmERICAN, Indian, and Canadian Domestic Policies
}

\author{
Marcy J. Robles \\ Elisabeth Haub School of Law at Pace University, New York, USA \\ marcyjrobles@gmail.com
}

ROBLES, Marcy, J, Child Marriage and the Failure of International Law: a Comparison of American, Indian, and Canadian Domestic Policies. International and Comparative Law Review, 2018, vol. 18, no. 1, pp. 105-125. DOI: 10.2478/iclr2018-0028.

\begin{abstract}
Summary: What is child marriage? The recognized definition does not adequately encompass the experience of child marriage. Child marriage stems from many elements, including coercion, force, and economic deprivation. Furthermore, child marriages have a long-term effect on child spouses, ranging from psychological damage, to health complications, to education and personal limitations. This paper argues that current international treaties and agreements do not specifically or directly address the issue of child marriage. Of those that make an attempt to, fail as a result of lack of enforcement or too much deference to religion as an exception of child marriage prohibition. In comparing three countries - The United States, India, and Canada, it is clear that Canadian policies work best and should be implemented on a larger scale. Current U.S. policies do not fully combat the child marriage phenomena, and although it is ahead of India in this area, it still has a long way to go in terms of development.
\end{abstract}

Keywords: international law, comparative, Canada, India, United States, international human rights, marriage, child, child marriage, family law.

\section{Introduction}

Marriage is usually viewed as a cause for celebration. It is a joyous occasion that enjoins two individuals as one. In society, marriage is viewed as the embodiment of a couple's love. ${ }^{1}$ In fact, love is seen as the main foundation in which a marriage is built. ${ }^{2}$ Ninety-three percent of married people say that love is a very important reason to get married; eighty-four percent of unmarried people agree with this sentiment. ${ }^{3}$ In fact, it appears that love is perhaps the main reason a

160 MINUTES/VANITY FAIR. What Do Americans Think of Marriage?, [online]. Available at: <https://www.vanityfair.com/culture/2017/01/what-do-americans-think-of-marriage > Accessed: 11/03/2018

2 COHN, D'vera. Love and Marriage. [online]. Available at: <http://www.pewsocialtrends. org/2013/02/13/love-and-marriage/> Accessed: 01/05/2018

3 Id. See also GEIGER, Abigail, LIVINGSTON, Gretchen. 8 facts about love and marriage

Published by Palacký University Olomouc, Czech Republic, 2018.

ISSN (print): 1213-8770; ISSN (online): 2464-6601 
person gets married, and other factors, such as financial stability, legal rights and benefits, etc. pale in comparison to love. ${ }^{4}$ The idea that nothing is more fulfilling than finding your one true love and getting married has been reinforced in society time and time again. Marriage is often seen as the most important event or milestone in one's lifetime, ${ }^{5}$ and "for those who have never wed, marriage remains a life goal." ${ }^{\prime}$ However, society does not seem to be in a rush to achieve the life goal of marriage. ${ }^{7}$ In 2017, the United States Census Bureau found that "the median age at first marriage had reached its highest point on record: 29.5 years for men and 27.4 years for women." ${ }^{8}$ Why? Well, the most frequently cited reason for young adults - ages eighteen to twenty-four - is that they are not ready to settle down, or simply, are too young to do so. ${ }^{9}$ However, despite this widespread consensus, many individuals, particularly females, marry young and marry as children. The reasons for such child marriages vary, but one thing is clear: love is not a factor.

Part I of this note discusses background information regarding child marriages and why such marriages occur around the world. Part I will briefly touch upon the physical and psychological effects a marriage has on a child bride. Part I will also examine and discuss several international treaties and other international instruments that demonstrate a strong stance against child marriages. Part II of this note examines how these international instruments play out in three countries - United States, India, and Canada - in conjunction with that country's domestic law. Part II of this note will also compare each country's child marriage trends, laws, and policies. Lastly, this note will conclude with a summary of findings and highlight successful approaches to combat child marriages.

in America. [online]. Available at: <http://www.pewresearch.org/fact-tank/2018/02/13/8facts-about-love-and-marriage/> Accessed: 11/03/2018 ("About nine-in-ten Americans $(88 \%)$ cited love as a very important reason to get married.").

4 Id.

5 This idea is universal and can be seen around the world. See e.g., KIM, Shidug. Wedding Culture as a Traditional Ritual. [online]. Available at: <http://ichcourier.ichcap.org/en/ wedding-culture-as-a-traditional-ritual-2/> Accessed: 11/03/2018

6 COHN, D'vera. Supra note 2. ("About six-in-ten (61\%) men and women who have never married say they would like to get married, according to the 2010 Pew Research survey.").

7 GEIGER, Abigail, LIVINGSTON, Gretchen. Supra note 3.

8 Id.

9 WANG, Wendy, PARKER, Kim. Chapter 1: Public Views on Marriage. [online]. Available at: <http://www.pewsocialtrends.org/2014/09/24/chapter-1-public-views-on-marriage/> Accessed: 11/03/2018 


\section{What is Child Marriage?}

Imagine you are ten years old. ${ }^{10}$ Your parents tell you that there is a party in the forest - a celebration. ${ }^{11}$ You attend the party only to find out is it your wedding and you are being sent away. ${ }^{12}$ Everyone knew you were getting married except you. ${ }^{13}$ A stranger - your husband? - grabs you by force and takes you away. ${ }^{14}$ You cry, but it does not make a difference. ${ }^{15}$

Imagine you are twelve years old. ${ }^{16}$ Your father tells you and your fourteenyear-old sister that you are going on vacation in another country. ${ }^{17}$ Excited, you pack your bags. Upon arrival to the other country, you find out your father sold you and your sister as wives. ${ }^{18}$ You are thereafter imprisoned, beaten, raped, and forced into domestic slavery. ${ }^{19}$ This continues for eight years until you manage to escape. ${ }^{20}$ Yet upon escape, you worry about the child you left behind. ${ }^{21}$

These appalling scenarios are based on true life testimonials and unfortunately occur more often than we think. In fact, one in three girls in the developing world are said to be married before eighteen and over 700 million women alive today were married as children. ${ }^{22}$ Such testimonials demonstrate what child marriage is and what it is not. Child marriage is not full of love and romance - factors that most individuals equate with marriage. Child marriage is full of pain, suffering, and brutality - factors that all children should not be forced to undergo. For the child coerced into it, child marriage is torture. "Each year, 15 million girls are married before the age of 18 . That is 28 girls every minute. One every 2 seconds." ${ }^{23}$ If this pattern continues and there is no decline in child marriages, by 2050, 1.2 billion women will have been married as children. ${ }^{24}$

10 The scenario is drawn from real life testimonial. Early Marriage: Sexual Exploitation \& The Human Rights of Girls. The Forum on Marriage and the Rights of Women and Girls, 2001., pp. 9. Available at: <http://www.crin.org/docs/resources/publications/1367EarlyMarriage. pdf> Accessed: 11/03/2018 ("When I was 10 my parents arranged for me to marry in the forest. They pretended it was just a party. But it was a wedding and they sent me away. My mother never told me I was going to be married. They came and took me by force. I cried but it didn't make any difference.").

11 Id.

12 Id.

13 Id.

14 Id.

15 Id.

16 Id. at 14.

17 Id.

18 Id.

19 Id.

20 Id.

21 Id.

22 GIRLS NOT BRIDES. About Child Marriage. [online]. Available at: <https://www.girlsnotbrides.org/about-child-marriage/> Accessed: 11/03/2018.

23 Id.

24 Id. 
The recognized definition of child marriage - "any formal marriage or informal union where one or both of the parties are under 18 years of age"25 - does not encompass the experience of child marriage. As demonstrated by the aforementioned scenarios, a child marriage is usually arranged by the child's parents, and the child is customarily a female. ${ }^{26}$ Without the child's knowledge, the parents select a spouse for the child and organizes a settlement with the potential spouse or the potential spouse's family. ${ }^{27}$ Sometimes the potential spouse is also a child, but on most occasions, this is not the case. ${ }^{28}$ In fact, typically the potential spouse is drastically older than the child - sometimes old enough to be a parent or grandparent. ${ }^{29}$ When girls are subjected to marriage at such a young age, they lack the capacity and choice to give full consent. ${ }^{30}$ When legal consent is absent, as it always is in regards to child marriage, such a marriage only be seen as coercion. ${ }^{31}$

\subsection{Repercussions of Child Marriage and the Factors That Provoke it}

Major factors that determine whether a child is at risk of child marriage include poverty, family stability, family honor, protection of girls, amongst others. ${ }^{32}$ Child marriage is prominent amongst poor groups in society. ${ }^{33}$ The reason for this is perhaps because child marriage is often viewed as a "strategy for economic survival."34 Young girls may be seen as an economic burden on their families. ${ }^{35}$ For this reason, a marriage to a much older individual who can offer the family wealth in exchange for the marriage can be seen as a necessity to relieve economic stress. ${ }^{36}$ Child marriage is also a way to ensure that the young girl is protected by being placed under male control. ${ }^{37}$ The intent behind this is that families want to discourage premarital sex or illegitimate children. ${ }^{38}$ Also,

25 Id.

26 See generally UNITED NATIONS CHILDREN'S FUND INNOCENTI RESEARCH CENTRE. Early Marriage: Child Spouses. Innocenti Digest, 2001, no. 7. Available at: <https:// www.unicef-irc.org/publications/pdf/digest7e.pdf> Accessed: 11/03/2018; INTERNATIONAL HUMANIST AND ETHICAL UNION. Child Marriage: A Violation of Human Rights. [online]. Available at: <http://iheu.org/child-marriage-violation-human-rights/> Accessed: 11/03/2018

27 Id.

28 Id.

29 Id.

30 Id.

31 Id.

32 Id.

33 INTERNATIONAL HUMANIST AND ETHICAL UNION. Supra note 26.

34 UNITED NATIONS CHILDREN'S FUND INNOCENTI RESEARCH CENTRE. Supra note 26 .

35 Id.

36 Id.

37 Id.

38 Id. 
they want to protect the girl from undesired male sexual attention. ${ }^{39}$ Other factors, such as a country's political condition or health condition can lead to an increase of child marriages. ${ }^{40}$ For example, a country ridden with HIV infection can encourage men to seek young virgins - that way they have a guarantee that their child bride is uninfected. ${ }^{41}$

There are many repercussions and consequences a forced marriage can have on a child. These consequences include, but are not limited to both physical and psychological health deterioration. ${ }^{42}$ Child brides are forced to have sexual intercourse with their older husbands. ${ }^{43}$ The husbands may have been in previous relationships, or simply may not be monogamous. ${ }^{44}$ This can open the child up to sexually transmitted diseases. ${ }^{45}$ The child's age difference with her husband, perhaps combined with her low economic status, makes it impossible to demand faithfulness or protected sex. ${ }^{46}$ Even if the child bride does not contract a sexually transmitted disease, forced sexual relations often leads to pregnancy. ${ }^{47}$ There is a strong correlation between age and mortality when females become pregnant. ${ }^{48}$ Girls ages ten to fourteen are five times more likely to die in pregnancy or childbirth than women aged twenty to twenty-four and girls aged fifteen to nineteen are twice as likely to die. ${ }^{49}$ The body of a young girl is not yet ready for pregnancy and childbirth, which leads to health complications. ${ }^{50}$

39 Id.

40 Id.

41 Id.

42 INTERNATIONAL HUMANIST AND ETHICAL UNION. Supra note 26. See also WORLD POLICY ANALYSIS CENTER. Assessing National Action on Protection from Child Marriage. [online]. Available at: <https://www.worldpolicycenter.org/sites/default/ files/WORLD_Fact_Sheet_Legal_Protection_Against_Child_Marriage_2015.pdf> Accessed: 11/03/2018 ("Early marriage jeopardizes girls' health due to abuse, limited control over their own bodies and their sexual and reproductive health decisions, and early pregnancy and childbearing.").

43 Id.

44 Id.

45 Id.

46 Id.

47 Id.

48 Id.

49 INTERNATIONAL HUMANIST AND ETHICAL UNION. Supra note 26.

50 Id. Obstructed labour is a common health consequence for child brides. See DOLEA, Carmen, ABOUZAHR, Carla. Global burden of obstructed labour in the year 2000. [online]. Available at: <http://cdrwww.who.int/healthinfo/statistics/bod_obstructedlabour.pdf> Accessed: 11/03/2018 ("Labour is considered obstructed when the presenting part of the fetus cannot progress into the birth canal."). Obstructed labour often leads to obstetric fistula. See UNITED NATIONS POPULATION FUND. Obstetric fistula. [online]. Available at: <https://www.unfpa.org/obstetric-fistula $>$ Accessed: 11/03/2018 ("Obstetric fistula is one of the most serious and tragic childbirth injuries. It is a hole between the birth canal and bladder or rectum caused by prolonged, obstructed labour, without access to timely, high-quality medical treatment. It leaves women leaking urine, faeces or both, and often leads to chronic medical problems, depression, social isolation and deepening poverty. 
Furthermore, due to a child bride's "limited autonomy or freedom of movement," she often has no access to health services to address said complications or take preventative measures. ${ }^{51}$

Child brides are more likely to experience domestic violence - "[w]omen married before the age of 18 are three times more likely to have been beaten by their spouse than women married at age 21 or older." ${ }^{52}$ Girls in this situation are least likely to take action against such abuses. ${ }^{53}$ Child marriage limits personal development, often leading to negative psychological damage. ${ }^{54}$

Lastly, "[g]ender inequality is both a cause as well as a consequence of child marriage." 55 In fact, data from several countries in Africa suggests that child marriage accounts for twelve to twenty-two percent of school dropouts among girls. ${ }^{56}$ In other words, females who get married at an older age have a higher education than those who get married as children. ${ }^{57}$ In considering all of these aspects, it is clear that child marriage - and all the factors that coincide with it, such as low levels of education and high levels of violence, abuse, and health deterioration - results in an increased vulnerability on the part of the child bride and an increased empowerment on the part of the spouse, creating a damaging and destructive power dynamic. ${ }^{58}$ Simply put, the elements and factors that surround child marriages makes it a clear violation of human rights. ${ }^{59}$

\subsection{International Human Rights Law on Child Marriages}

International human rights law takes a strong position against child marriages but does not address the phenomenon as its own category. ${ }^{60}$ Instead, the

More than 2 million women ... are estimated to be living with fistula, and some 50,000 to 100,000 new cases develop annually. Yet fistula is almost entirely preventable. Its persistence is a sign of global inequality and an indication that health systems are failing to protect the health and human rights of the poorest and most vulnerable women and girls.").

51 INTERNATIONAL HUMANIST AND ETHICAL UNION. Supra note 26.

52 WORLD POLICY ANALYSIS CENTER. Assessing National Action on Protection from Child Marriage. [online]. Available at: <https://www.worldpolicycenter.org/sites/default/ files/WORLD_Fact_Sheet_Legal_Protection_Against_Child_Marriage_2015.pdf> Accessed: 11/03/2018

53 INTERNATIONAL HUMANIST AND ETHICAL UNION. Supra note 26.

54 Id.

55 Id.

56 WORLD POLICY ANALYSIS CENTER. Supra note 52.

57 INTERNATIONAL HUMANIST AND ETHICAL UNION. Supra note 26.

58 Id.

59 Id.

60 STEWART, Terence P., SCHENEWERK, Caryn B. The Conflict Between Facilitating International Trade and Protecting U.S. Agriculture from Invasive Species: Aphis, The U.S. Plant Protection Laws, and the Argentine Citrus Dispute. Journal of Transnational Law and Policy, 2003, vol. 13, no. 2, pp. 305, 484. Available at: <http://www.law.fsu.edu/ docs/default-source/journals/jtpl/previous-issues/volume-13-number-2.pdf?sfvrsn=4> Accessed: 11/03/2018 ("The practice of early marriage has received little attention from 
international community has created various treaties and agreements relating to children or marriage generally ${ }^{61}$ For example, international human rights conventions have taken stances in issues that are frequently entwined with child marriage and marriage in general, such as sexual exploitation, child abuse, forced labor/slavery and human trafficking. ${ }^{62}$ Basic human principles - the lack thereof which are present in child marriages as well - such as the freedom of religion and freedom of autonomy are also addressed. ${ }^{63}$ As a whole, international law covers the rights of women, consent, and the like, but nothing explicitly dedicated to child marriage - in other words, "[t]here has been virtually no attempt to examine the practice [of child marriage] as a human rights violation in itself." ${ }^{\prime}$

Perhaps one of the most known international instrument addressing marriage, in which 48 countries are a party, ${ }^{65}$ is Article 16 of the 1948 Universal Declaration of Human Rights ("UDHR"), which recognizes that marriage must encompass free and full consent. ${ }^{66}$ The UDHR states:

1. Men and women of full age, without any limitation due to race, nationality or religion, have the right to marry and to found a family. They are entitled to equal rights as to marriage, during marriage and at its dissolution.

2. Marriage shall be entered into only with the free and full consent of the intending spouses.

3. The family is the natural and fundamental group unit of society and is entitled to protection by society and the State. ${ }^{67}$

Notice that the UDHR stresses that men and women of "full age" have a right to marry and are entitled to equal rights. When children are married to an older spouse, the power dynamic prohibits equality in the marriage. Furthermore,

women's and children's rights movements ....”). See also WARNER, Elizabeth. Behind the Wedding Veil: Child Marriage as a Form of Trafficking in Girls. Journal of Gender, Social Policy and Law, 2011, vol. 12, pp. 233, 247. Available at: <http://digitalcommons.wcl.american.edu/cgi/viewcontent.cgi?article=1310\&context=jgspl> Accessed: 11/03/2018 ("[I]t is striking how poorly existing international human rights and women's rights conventions address the practice of child marriage or the forms of abuse that can occur within such a marriage.").

61 WARNER, Elizabeth. Supra note 60. See also AFRICAN CHILD POLICY FORUM. Provisions of International and Regional Instruments Relevant to Protection from Child Marriage. [online]. Available at: <https://www.girlsnotbrides.org/wp-content/ uploads/2015/03/Intl-and-Reg-Standards-for-Protection-from-Child-Marriage-ByACPF-May-2013.pdf> Accessed: 11/03/2018

62 WARNER, Elizabeth. Supra note 60.

63 Id.

64 UNITED NATIONS CHILDREN'S FUND INNOCENTI RESEARCH CENTRE. Supra note 26, pp. 2-3.

65 Unless noted otherwise, assume that the United States, Canada, and India are parties to the international agreements mentioned hereinafter.

66 Universal Declaration of Human Rights, 1948, art. 16. [online]. Available at: <http://www. ohchr.org/EN/UDHR/Documents/UDHR_Translations/eng.pdf.> Accessed: 11/03/2018

67 Id. (emphasis added). 
"full age" implies that those who have not reached full age cannot be capable of consent. However, such an inference is not enough and simply overlooks child marriage as a separate, significant issue. ${ }^{68}$ Many other international documents echo the same idea as the UDHR, placing its focus on marriage generally. ${ }^{69}$ For example, one major multi-lateral treaty that has 170 parties, Article 23 of the International Covenant on Civil and Political Rights, states:

1. The family is the natural and fundamental group unit of society and is entitled to protection by society and the State.

2. The right of men and women of marriageable age to marry and to found a family shall be recognized.

3. No marriage shall be entered into without the free and full consent of the intending spouses.

4. States Parties to the present Covenant shall take appropriate steps to ensure equality of rights and responsibilities of spouses as to marriage, during marriage and at its dissolution. In the case of dissolution, provision shall be made for the necessary protection of any children. ${ }^{70}$

The International Covenant on Civil and Political Rights recognizes the right of men and women of "marriageable age" and echoes UDHR's idea of "free and full consent." ${ }^{\prime 1}$ However, like "full age," "marriageable age" is not expressly defined. ${ }^{72}$ Is a female considered "full age" and "marriageable age" upon receiving her first menstrual cycle ? $^{73}$ What if she receives her first menstrual cycle at age ten? Again, "free and full consent" implies that children should not be entering marriage as they lack the capacity to consent. The International Covenant on Civil and Political Rights does mention "the necessary protection" of children,

68 Accord BROWN, Gordon. Children left out of Universal Declaration of Human Rights. [online]. Available at: <https://www.bostonglobe.com/opinion/2016/04/17/childrenleft-out-universal-declaration-human-rights/wjYQ1rDfglEWu4lmowtczJ/story.html> Accessed: 11/03/2018

69 See, for example, 1979 Convention on the Elimination of All Forms of Discrimination against Women, art. 16.1, Dec. 18, 1979, 1249 U.N.T.S. 13 (“(a) The same right to enter into marriage; (b) The same right freely to choose a spouse and to enter into marriage only with their free and full consent.") [hereinafter "CEDAW"]. CEDAW was ratified by 189 states, including India and Canada, and excluding the United States. See also 1956 Supplementary Convention on the Abolition of Slavery, the Slave Trade, and Institutions and Practices Similar to Slavery, art. 1(c), Sept. 7, 1956, 226 U.N.T.S. 3, entered into force April 30, 1957. ("Any institution or practice whereby: (i) A woman, without the right to refuse, is promised or given in marriage on payment of a consideration in money or in kind to her parents, guardian, family ....”). This Convention has 35 signatories, including Canada and India, and excluding the United States.

70 International Covenant on Civil and Political Rights, art. 23, Dec. 16, 1966, 999 U.N.T.S. 171. [online]. Available at: <http://www.ohchr.org/Documents/ProfessionalInterest/ccpr. pdf $>$ Accessed: 11/03/2018 (emphasis added).

71 Id.

72 Id.

73 Many countries consider a female's first menstrual cycle to be a mark of womanhood/ adulthood. 
but only in the context of marriage dissolution between the child's parents, not "the necessary protection" of children in the context of child marriages. ${ }^{74}$

However, several international agreements, unlike the UDHR, take more of a direct notice of child marriage. Take the 1964 Convention on Consent to Marriage for example, which only has sixteen signatories, including the United States and excluding India and Canada. ${ }^{75}$ The 1964 Convention on Consent to Marriage states,

(1) No marriage shall be legally entered into without the full and free consent of both parties, such consent to be expressed by them in person ... as prescribed by law. (2) States Parties to the present Convention shall ... specify a minimum age for marriage ("not less than 15 years" according to the non-binding recommendation accompanying this Convention). No marriage shall be legally entered into by any person under this age, except where a competent authority has granted a dispensation as to age, for serious reasons, in the interests of the intending spouses .

.. (3) All marriages shall be registered . . by the competent authority. ${ }^{76}$

Similar to the UDHR, the 1964 Convention on Consent to Marriage ("1964 Convention") portrays the idea of "full and free consent of both parties."77 The 1964 Convention takes it a step further by providing a minimum threshold in which a child can get married - age fifteen. ${ }^{78}$ However, the 1964 Convention provides an exception, allowing a "competent authority" to overlook the age minimum in special circumstances. ${ }^{79}$ As we will see later, such exceptions, and other similar allowances, provide too much leeway and loopholes, weakening the strength of such international agreements. Other international agreements, similarly to the 1964 Convention, mention a minimum age for marriage, but allow a State's legislature to decide the minimum age. ${ }^{80}$ Even international agreements and treaties that address child marriages with less vagueness ${ }^{81}$ tend to fail - mostly due to a lack of enforcement.

All in all, these international treaties and agreements fail for several reasons. First is that they lack enforcement and are not self-executing. ${ }^{82}$ The language in which the international agreements are too general and leave it to domestic leg-

74 International Covenant on Civil and Political Rights. Supra note 70.

751964 Convention on Consent to Marriage, Minimum Age for Marriage and Registration of Marriages, art. 1-3, Dec. 23, 1964, 521 U.N.T.S. 231.

76 Id.

77 Id.

78 Id.

79 Id.

80 CEDAW. Supra note 69.

81 See, for example, 1990 African Charter on the Rights and Welfare of the Child, art. XXI, July 1, 1990, OAU Doc.CAB/LEG/24.9/49 ("Child marriage and the betrothal of girls and boys shall be prohibited and effective action, including legislation, shall be taken to specify the minimum age of marriage to be eighteen years."). This is a regional treaty in which Canada, India, and the United States are not parties to.

82 WARNER, Elizabeth. Supra note 60. 
islature to adopt laws that achieve the desired goals. ${ }^{83}$ As briefly outlined above, the age of majority is vague and not expressly defined. ${ }^{84}$ Furthermore, the international treaties and agreements leave it to domestic legislation to determine a mandatory minimum age ${ }^{85}$ Full and free consent is a reoccurring theme, but children are frequently overlooked and simply not mentioned, underlining the vulnerabilities that children have. ${ }^{86}$

Furthermore, as mentioned previously, certain loopholes and exceptions are in place that prevent the enforcement of the international treaties and agreements. For example, religious practices often triumph over the international agreements and treaties as the conventions defer greatly to religion..$^{87}$ This allows for a religious exemption, overcoming laws that prohibit child marriage. ${ }^{88}$ "In many countries, early marriage falls into what amounts to a sanctions limbo. It may be prohibited in the existing civil or common law, but be widely condoned by customary and religious laws and practice." ${ }^{89}$ This creates a complicated situation in which legislation is created to combat child marriage, yet is not enforced because there is an understanding that "many customary practices would continue even if they were inconsistent with new laws." ${ }^{30}$ In essence, the international treaties and agreements set forth to combat child marriage to some extent or another, are useless. Unless a specific instrument is designed to meet the needs of child spouses - one in which outlines enforcement, minimum age, and all of the factors previously mentioned - child marriage will remain an issue worldwide.

\section{As a Result of Lax International Law, Countries' Domestic Child Marri- age Policies Fall in all Ends of a Spectrum, With Canada Being Superior}

3.1 Child Marriage is an Issue in the United States Due to Exceptions in the Law and Inconsistencies Throughout the Fifty States

Consider the United States: child marriage, although not as rampant as compared to other countries, is still a problem in the U.S. ${ }^{91}$ Unfortunately, child marriage occurs more often than we think. In fact, it is significant and widespread,

83 Id.

84 Id.

85 Id.

86 Id.

87 Id.

88 Id.

89 UNITED NATIONS CHILDREN'S FUND INNOCENTI RESEARCH CENTRE. Supra note 26.

90 Id.

91 See generally Unchained. [online]. Available at: <http://www.unchainedatlast.org> Accessed: 11/03/2018; SEILER, Naomi. Is Teen Marriage a Solution? [online]. Available at: <https://www.clasp.org/sites/default/files/public/resources-and-publications/ archive/0087.pdf.> Accessed: 11/03/2018 
yet largely ignored..$^{92}$ As of February 2017, over 248,000 children had been married in the United States between 2000 and 2010, mostly to adult men. ${ }^{93}$ In the U.S. federal system, state legislatures set the minimum age of marriage for each state. ${ }^{94}$ The minimum age of marriage in most U.S. states is eighteen, but exceptions in every state allow those younger than eighteen years of age to marry. ${ }^{95}$ Twenty-seven states do not set a minimum age below which a child cannot marry. ${ }^{96}$ Furthermore, no concrete federal laws exist concerning child marriage in the United States. ${ }^{97}$ However, Congress has demonstrated its awareness of the global problems associated with child marriage - perhaps as an effort to avoid addressing the issue domestically, or simply ignore it. ${ }^{98}$

Currently, the International Protecting Girls by Preventing Child Marriage Act is pending in Congress. ${ }^{99}$ It defines child marriage as a human rights violation. ${ }^{100}$ The Act states that child marriage "produces devastating repercussions for a girl's life, effectively ending her childhood' by forcing her 'into adulthood and motherhood before she is physically and mentally mature."'101 The Act's goal is "to protect girls in developing countries through the prevention of child marriage ...."102 Sponsors hope to classify child marriage as a human rights violation and to articulate efforts to combat child marriage as a U.S. foreign policy goal. ${ }^{103}$ The Act projects that more than 100 million girls in developing countries will

92 Unchained. Supra, note 91.

93 Id.

94 Id.

95 Id.

96 Id.

97 Id.

98 See REISS, Fraidy. Why can 12-year-olds still get married in the United States? [online]. Available at: <https://www.washingtonpost.com/posteverything/wp/2017/02/10/whydoes-the-united-states-still-let-12-year-old-girls-get-married/?postshare=7014868502161 67\&utm_term=.eb1a1dd94217> Accessed: 11/03/2018 ("[S]tate lawmakers have resisted passing legislation to end child marriage - because they wrongly fear that such measures might unlawfully stifle religious freedom or because they cling to the notion that marriage is the best solution for a teen pregnancy.").

99 International Protecting Girls by Preventing Child Marriage Act of 2012, H.R. 6087, 112th Cong. (2012).

100 Id.

101 International Protecting Girls by Preventing Child Marriage Act of 2012, H.R. 6087, 112th Cong. (2012).

102 Id.

103 Id. See also TERKEL, Amanda. House Republicans Block Child Marriage Prevention Act. [online]. Available at: <http://www.huffingtonpost.com/2010/12/17/house-republicansblock-child-marriage-prevention-act_n_798382.html> Accessed: 11/03/2018 ("In 2010 Congress attempted to pass an earlier version of this bill. It was unanimously approved by the Senate, but failed in the House of Representatives. This was because House Republicans were adamantly against it. They argued that it was too expensive and would lead to an increase in abortions. Bill advocates responded that it would cost no more than $\$ 1$ million and sought only to clarify child marriage as a human rights violation and U.S. foreign policy priority."). 
be married before the age of eighteen over the next decade. ${ }^{104}$ Furthermore, it recognizes that the "risks of child marriages include poverty, low educational opportunities, low employment opportunities, health problems, maternal death and morbidity, infant death and morbidity, sexually transmitted diseases, and AIDS." ${ }^{105}$ The bill's language suggests the U.S. Congress believes the appropriate age for marriage is eighteen, yet the U.S. tolerates marriage below that age. ${ }^{106}$

Consider this Washington Post article, entitled Why can 12-year-olds still get married in the United States? ${ }^{107}$ The article discusses the true-life experience of Michelle DeMello, who was coerced into marrying at age sixteen, mainly to save her family's honor. "[I]n 38 states, more than 167,000 children - almost all of them girls, some as young 12 - were married during that period, mostly to men 18 or older." ${ }^{108}$ While numbers are not as dire as others around the world, they are still alarmingly high enough to warrant attention. ${ }^{109}$ Idaho in particular has the highest rate of child marriage - between 2000 and 2010, fifty-five girls under the age of sixteen were married to men eighteen or older. ${ }^{110}$ U.S. girls who marry before nineteen are fifty percent more likely than their unmarried peers to drop out of high school and four times less likely to graduate from college. ${ }^{111}$ A girl who marries young is thirty-one percentage more likely to live in poverty when she is older. ${ }^{112}$ Furthermore, those who marry before the age of eighteen face a twenty-three percent higher risk of heart attack, diabetes, cancer and stroke than do women who marry between ages nineteen and twenty five. ${ }^{113}$ Also, "[w] omen who wed before 18 also are at increased risk of developing various psychiatric disorders, even when controlling for socio-demographic factors." 114 Just recently, U.S. States have been trying to patch up flaws in child marriage laws, such as Virginia with its 2016 legislation. ${ }^{115}$

Consider a 2009 Alabama case, called State Dep't of Human Res. v. Lott, which allowed a marriage between a nineteen and thirteen old and rendered it valid. ${ }^{116}$

104 Id.

105 International Protecting Girls by Preventing Child Marriage Act of 2012, H.R. 6087, 112th Cong. (2012).

106 Id.

107 REISS, Fraidy. Supra note 98.

108 Id.

109 Id.

$110 \mathrm{Id}$. This finding is out of the states who actual provide data on child marriages - many states do not keep track of such information, and often, child brides are either taken oversees to get marries or wed in religious ceremonies.

111 Id. See also DAHL, Gordon B. Early Teen Marriage and Future Poverty. [online]. Available at: <http://www.nber.org/papers/w11328.pdf> Accessed: 11/03/2018

112 Id.

113 Id.

114 Id.

115 Id.

116 State Dep’t of Human Res. v. Lott, 16 So. 3d 104 (2009 Ala.). 
The reason? Pregnancy. Alabama law provided that girls under age sixteen are unable to marry unless they are pregnant. ${ }^{117}$ The pregnancy needs to be verified via physician, the father needs to establish paternity, and the girl needs to get parental consent. ${ }^{118}$ Does this mean that premarital sex negates ${ }^{119}$ the fact that child marriage "'produces devastating repercussions for a girl's life, effectively ending her childhood' by forcing her 'into adulthood and motherhood before she is physically and mentally mature[?]"'120

\subsection{Child Marriage Runs Rampant in India Due to Custom and Legal Shortfalls}

As unfortunate the statistics are for the United States, it is at least not as bad as a developing country such as India. India has the highest absolute number of child marriage at $26,610,000^{121}$ and more than forty percent of the world's child marriages happen in India. ${ }^{122}$ The reason for this is perhaps because it is custom for families to give very small children away in marriage. ${ }^{123}$ In fact, this practice dates back to India's ancient period and children as young as six or eight were married during medieval times. ${ }^{124}$ The trend continued today and resulted in a practiced known as Atta Satta. ${ }^{125}$ "[Atta Satta] is a practice of exchanging a daughter in return for a daughter-in-law in marriage to their son." ${ }^{126}$ Some girls as young as four or five are married off as a result of this practice. ${ }^{127}$ Furthermore, "[o]n the auspicious day of Akha Teej, the mass solemnization of marriages between young boys and girls is performed." ${ }^{128}$ Akha Teej is considered a good day of prosperity to establish new ventures, including marriages. ${ }^{129}$ "From the parents' point of view, this is the tried and tested way of organizing the passing on of property and wealth within the family." ${ }^{130}$ Additionally, a significant fraction of the children involved are under the age of ten, sometimes as young

117 Id.

118 Id.

119 See generally State v. Ward (1944) (A twenty-six-year-old man brought a thirteen-year-old girl to his mother's house, introduced her to his family as his wife, and brought her into his bedroom to have intercourse with her. The man's father decided that he wanted the girl and his son to marry, so the twenty-six-year-old obtained a marriage license from a judge).

120 REISS, Fraidy. Supra note 98.

121 See GIRLS NOT BRIDES. Supra note 22.

122 ARJUNPURI, Chaitra. Akshaya Tritiya: Hotbed of child marriages. [online]. Available at: <https://www.aljazeera.com/indepth/features/2012/04/201242465347804562.html> Accessed: 11/03/2018

123 See United Nations Children's Fund Innocenti Research Centre. Supra note 26 at 2.

124 ARJUNPURI, Chaitra. Supra note 122.

125 Id.

126 Id.

127 Id.

128 United Nations Children's Fund Innocenti Research Centre. Supra note 26 at 2.

129 ARJUNPURI, Chaitra. Supra note 122.

130 United Nations Children's Fund Innocenti Research Centre. Supra note 26 at 2. 
as two or three-years-old. ${ }^{131}$ In India, the legal age to get married is eighteen for girls and twenty-one for boys, but this threshold is widely disregarded in practice and in fact, India is home to one in three of the world's child brides. ${ }^{132}$ A family health survey conducted by the Indian government finds that about forty-seven percent of girls twenty to twenty-four years of age were married or had entered into a union before the legal age. ${ }^{133}$ Other factors, aside from custom, that contribute to the trend of child marriage include poverty, lack of education, gender/ social norms, and more. ${ }^{134}$

The Indian government has taken various measures to combat child marriages. In 2006, it passed the Prohibition of Child Marriage Act. ${ }^{135}$ This prohibition increased penalties for conducting marriage ceremonies for underage couples and making marriages open to annulment by either spouse for up to two years after reaching legal age. ${ }^{136}$ Those who are found guilty of marrying girls under age eighteen can face either two years of imprisonment or a fine of $\$ 1,900$, or both. ${ }^{137}$ However the law "still remains unimplemented in many tribal districts in the country." 138 The reason for this is perhaps because many state officers are burdened with their primary work and therefore do not prioritize the prevention of child marriages. ${ }^{139}$ Another reason could be because various legal gaps in India's 2006 Prohibition of Child Marriage Act exist that prevent the prohibition on child marriages from being fully enforced. ${ }^{140}$ One crippling gap is that child marriages are voidable instead of void. ${ }^{141}$ In other words, a child bride has the option of annulling the marriage by filing a petition in district court. ${ }^{142}$ Given that child marriages are based upon a destructive power dynamic, it is really logical to assume a child bride will have the opportunity or knowledge to pursue an annulment? Even if she did, her options after annulment are limited as, in par with Indian custom, her family would most likely view her actions as dishonorable. Another huge criticism of the 2006 Prohibition of Child Marriage Act is the fact that India focuses on punishing the spouse of the child bride instead of also

131 Id.

132 MOHAN, Rohini. Troubled Waters: Child Brides in Flood-ravaged Assam, India. [online]. Available at: <http://projects.aljazeera.com/2014/child-marriage/india.html> Accessed: $11 / 03 / 2018$

133 Id.

134 KOLISETTY, Akhila. Child Marriage in India: Loopholes in the Law. [online]. Available at: $<$ https://ilg2.org/2015/07/02/child-marriage-in-india-loopholes-in-the-law/> Accessed: $11 / 03 / 2018$

135 MOHAN, Rohini. Supra note 132.

136 Id.

137 ARJUNPURI, Chaitra. Supra note 122.

138 Id.

139 Id.

140 KOLISETTY, Akhila. Supra note 134.

141 Id.

142 Id.

Published by Palacký University Olomouc, Czech Republic, 2018.

ISSN (print): 1213-8770; ISSN (online): 2464-6601 
targeting government officials who conduct the marriage. ${ }^{143}$ If prosecuting government officials who conduct child marriages was the law, said officials would most likely be deterred from holding child marriage ceremonies, thus preventing the phenomenon overall. ${ }^{144}$ Lastly, there are not many non-governmental organizations that exclusively deal with child marriages, nor does the 2006 Prohibition of Child Marriage Act create one for this purpose. ${ }^{145}$

Despite the 2006 Prohibition of Child Marriage's shortfall, India still demonstrates other efforts to combat child marriage. In 2013, the Court in Independent Thought $v$. Union of India held that "[i]f a man has sexual intercourse with a wife who is below 18 years, it will be an offence of Rape."146 This holding was a huge breakthrough in terms of child marriage laws. However, despite this breakthrough, child marriage remains rampant as oftentimes the spouse of a child bride waits until the child reaches the age of majority to have sexual intercourse. ${ }^{147}$ India continues its efforts through its membership in the South Asian Initiative to End Violence Against Children ("SAIEVAC"), which adopted a regional action plan to end child marriage. ${ }^{148}$ The regional action plan began in 2015 and is still being implemented. ${ }^{149}$ Although the Indian government has demonstrated efforts to reduce child marriages overall, early marriages are difficult to identify, report and prevent. ${ }^{150}$

\subsection{Child Marriage is Absolutely Illegal in Canada Due to Strict Regulations} and Strong Advocacy

Canada is perhaps the best country whose domestic policies adequately combat child marriages. ${ }^{151}$ Before 2015, Canadian provinces and territories operated the same way as the United States did: allowing some children as young as twelve

143 Id. See also ARJUNPURI, Chaitra. Supra note 122.

144 Id.

145 ARJUNPURI, Chaitra. Supra note 122.

146 CHAUDHRY, Disha. Child Marriage before the Indian Supreme Court. [online]. Available at: <http://ohrh.law.ox.ac.uk/child-marriage-before-the-indian-supreme-court/> Accessed: 11/03/2018

147 ARJUNPURI, Chaitra. Supra note 122.

148 See GIRLS NOT BRIDES. India. [online]. Available at: <https://www.girlsnotbrides.org/ child-marriage/india/> Accessed: 11/03/2018

149 Id.

150 MOHAN, Rohini. Supra note 132.

151 See, for example, Office of the High Commissioner for Human Rights. Canadian efforts to address child, early and forced marriage. [online]. Available at: <www.ohchr.org/ Documents/Issues/Women/WRGS/Earlyforcedmarriage/SG/Canada.docx $>$ Accessed: 19/04/2018; GIRLS NOT BRIDES. Canada. [online]. Available at: <https://www.girlsnotbrides.org/child-marriage/canada/> Accessed: 19/04/2018; GOVERNMENT OF CANADA. Child, early and forced marriage. [online]. Available at: $<\mathrm{http} / / /$ international. gc.ca/world-monde/issues_development-enjeux_developpement/human_rights-droits_ homme/child_marriage-mariages_enfants.aspx?lang=eng > Accessed: 19/04/2018 
years old marry on the basis of parental consent or pregnancy. ${ }^{152}$ However, that all changed in 2015 when Canada made amendments to the Civil Marriage Act. ${ }^{153}$ Now, unlike the United States, the minimum age of marriage in Canada, set by federal law, is sixteen. ${ }^{154}$ In other words, sixteen years old is the absolute minimum age of marriage, and accordingly, exceptions below this age is prohibited. ${ }^{155}$

Canada's 2015 Criminal Code ("Code") takes strides to combat child marriage. ${ }^{156}$ The Code makes it an offence to "celebrate[], aid[] or participate[] in a marriage ceremony with full knowledge that one of the persons being married is under the age of 16 years." 157 Those who do can face imprisonment of up to five years. ${ }^{158}$ This is unlike India, whose laws only punish the spouse of the child bride, whereas Canadian law essentially punishes everyone who partakes in the child marriage ceremony. Furthermore, Canadian punishment is stricter when compared to India, who imposes a two-year imprisonment or fine. Canada's Code also criminalizes individuals who remove a resident child from Canada with the purpose of marrying said child in another country. ${ }^{159}$ Moreover, Canadian courts have the "power to impose conditions on a person where there are reasonable grounds to fear that a forced or underage marriage will otherwise occur." ${ }^{160}$ Canadian Immigration Law and Regulations also combat child marriages. ${ }^{161}$ For instance, "a Canadian citizen or permanent resident must be at least 18 years of age in order to sponsor his or her spouse for permanent residence."162 This requirement potentially prevents young and vulnerable immigrant children from forced marriage. ${ }^{163}$

Arguably, the reason why Canada has been so successful with this endeavor is not only because of their legal enactments, but also their efforts in raising awareness. ${ }^{164}$ "Canada is a leading advocate and supporter for efforts to address

152 Office of the High Commissioner for Human Rights. Canadian efforts to address child, early and forced marriage. [online]. Available at: <www.ohchr.org/Documents/Issues/ Women/WRGS/Earlyforcedmarriage/SG/Canada.docx> Accessed: 19/04/2018 153 Id.

154 Id. See also GIRLS NOT BRIDES. Canada. [online]. Available at: <https://www.girlsnotbrides.org/child-marriage/canada/> Accessed: 19/04/2018; GOVERNMENT OF CANADA. Child, early and forced marriage. [online]. Available at: $<\mathrm{http}: / /$ international. gc.ca/world-monde/issues_development-enjeux_developpement/human_rights-droits_ homme/child_marriage-mariages_enfants.aspx?lang=eng > Accessed: 19/04/2018 155 Id.

156 Id.

157 Id.

158 Id.

159 Id.

160 Id.

161 Id.

162 Id.

163 Id.

164 Id. See also GIRLS NOT BRIDES. Canada. [online]. Available at: <https://www.girlsnotbrides.org/child-marriage/canada/> Accessed: 19/04/2018; GOVERNMENT OF 
child marriage [domestically and] internationally."165 Domestically, outreach and assistance are provided to non-governmental organizations working with victims of forced marriage in Canada. ${ }^{166}$ Training on child marriages are provided to boarder officers, front-line police officers, and other service providers. ${ }^{167}$ Furthermore, Canada has remained vocal on the issue of child marriage by conducting and participating in workshops, conferences, and knowledge exchanges. ${ }^{168}$ Canada's international efforts are also visible. ${ }^{169}$ In 2014, Global Affairs Canada established a Child, Early and Forced Marriage Unit. ${ }^{170}$ The purpose of creating this unit was to manage and organize Canada's international activities in support eliminating child marriages. ${ }^{171}$

Another reason why Canada is so successful in combating child marriage is due in part to its financial investments to the cause both within Canada and beyond its borders. ${ }^{172}$ For example, the Government of Canada demonstrated their commitment to end child marriage by dedicating CAN $\$ 80$ million towards the cause between 2011 and 2016. ${ }^{173}$ Additionally, in March 2017, the Trudeau government declared that over a three-year period, it was investing $\$ 650$ million towards procreative health, thus aiming to avoid and counter child marriages. ${ }^{174}$

In 2015, Canada provided international assistance by contributing $\$ 20$ million to a project designed "to help adolescent girls gain better access to health information and services, education and life skills training, while also generating valuable data that will be used for advocacy, training and project tracking." ${ }^{\prime 17}$ One of the countries the project aimed to help over the course of two years was India. ${ }^{176}$ That same year, Canada also dedicated $\$ 15.7$ million to Oxfam Canada. ${ }^{177}$ Specifically, the support was to benefit a project known as "Creating Space to Take Action on Violence Against Women and Girls" over the course of five

CANADA. Child, early and forced marriage. [online]. Available at: $<\mathrm{http} / /$ international. gc.ca/world-monde/issues_development-enjeux_developpement/human_rights-droits_ homme/child_marriage-mariages_enfants.aspx?lang=eng > Accessed: 19/04/2018

165 GIRLS NOT BRIDES. Canada. [online]. Available at: <https://www.girlsnotbrides.org/ child-marriage/canada/> Accessed: 19/04/2018; GOVERNMENT OF CANADA. Child, early and forced marriage. [online]. Available at: $<\mathrm{http} / / /$ international.gc.ca/world-monde/ issues_development-enjeux_developpement/human_rights-droits_homme/child_marriage-mariages_enfants.aspx?lang=eng $>$ Accessed: 19/04/2018

166 Id. See also Office of the High Commissioner for Human Rights. Supra note 152.

167 Office of the High Commissioner for Human Rights. Supra note 152.

168 Id.

169 Id.

170 Id.

171 Id.

172 Id. See also GIRLS NOT BRIDES. Canada. Supra note 165.

173 GIRLS NOT BRIDES. Canada. Supra note 165.

174 Id.

175 Office of the High Commissioner for Human Rights. Supra note 152.

176 Id.

177 Id. 
years. ${ }^{178}$ The project's purpose is to help reduce gender-based violence, including child marriages, through training and greater access to support services, such as legal advice in several countries, including India. ${ }^{179}$

\section{Conclusion}

Although international laws discourage underage marriage one way or another, it lacks the necessary elements to combat child marriage: enforcement, specificity, and inflexibility. The practice is widespread in some areas, due to religious deference, legislative lenience, lack of enforcement, etc. A multi-lateral treaty should be created to address child marriage explicitly and consider the elements that cause the phenomena to be widespread. The multi-lateral treaty should encompass factors such as enforcement, specificity, and strictness. At the very least, countries should model their domestic policies and actions after Canada. Canada's policies work best, particularly because its child marriage laws are enforced and decided on a province/territory level and federal level. Furthermore, Canadian law provides an absolute minimum age of sixteen for marriage, prohibiting any exceptions below this age. The Canadian government also makes it a crime to participate, aid, or celebrate child marriage - a crime punishable for up to five years in prison. The United States. is well on its way to patching up its child marriage phenomena; but will still continue to face underage marriage problems if not dealt with properly on a federal level by imposing an absolute minimum age requirement. The United States, like Canada, should also make efforts to raise awareness and provide financial assistance to non-governmental organizations in order to combat child marriages domestically. India, although on the right path, has legal gaps in their laws that make enforcement of said laws difficult. India should model some provisions of the 2006 Prohibition of Child Marriage Act after Canadian law. Particularly, India should expand the crime of child marriage to all of those who partake in it, instead of only criminalizing the spouse of the child bride. Furthermore, the Indian government should impose a stricter sentence than just two years or a fine. The Indian government should also make child marriage void instead of voidable. Although India is a developing country and may lack the finances to implement awareness projects or establish organizations who explicitly address child marriage, Canadian efforts abroad makes it clear that international assistance is available. In fact, Canada has contributed to projects that directly impact India. Little by little wins the race, but first, India must expand its 2006 Prohibition of Child Marriage Act.

\section{References}

1990 African Charter on the Rights and Welfare of the Child, art. XXI, July 1, 1990, OAU Doc.CAB/LEG/24.9/49.

178 Id.

179 Id. 
1979 Convention on the Elimination of All Forms of Discrimination against Women, art. 16.1, Dec. 18, 1979, 1249 U.N.T.S. 13.

1964 Convention on Consent to Marriage, Minimum Age for Marriage and Registration of Marriages, art. 1-3, Dec. 23, 1964, 521 U.N.T.S. 231.

1956 Supplementary Convention on the Abolition of Slavery, the Slave Trade, and Institutions and Practices Similar to Slavery, art. 1(c), Sept. 7, 1956, 226 U.N.T.S. 3, entered into force April 30, 1957.

60 MINUTES/VANITY FAIR. What Do Americans Think of Marriage?, [online]. Available at: <https://www.vanityfair.com/culture/2017/01/what-do-americansthink-of-marriage> Accessed: 11/03/2018

AFRICAN CHILD POLICY FORUM. Provisions of International and Regional Instruments Relevant to Protection from Child Marriage. [online]. Available at: $<$ https://www.girlsnotbrides.org/wp-content/uploads/2015/03/Intl-and-RegStandards-for-Protection-from-Child-Marriage-By-ACPF-May-2013.pdf> Accessed: 11/03/2018.

ARJUNPURI, Chaitra. Akshaya Tritiya: Hotbed of child marriages. [online]. Available at: <https://www.aljazeera.com/indepth/features/2012/04/201242465347804562. html> Accessed: 11/03/2018

BROWN, Gordon. Children left out of Universal Declaration of Human Rights. [online]. Available at: <https://www.bostonglobe.com/opinion/2016/04/17/children-left-out-universal-declaration-human-rights/wjYQ1rDfglEWu4lmowtczJ/ story.html> Accessed: 11/03/2018

CHAUDHRY, Disha. Child Marriage before the Indian Supreme Court. [online]. Available at: <http://ohrh.law.ox.ac.uk/child-marriage-before-the-indiansupreme-court/> Accessed: 11/03/2018

COHN, D’vera. Love and Marriage. [online]. Available at: <http://www.pewsocialtrends.org/2013/02/13/love-and-marriage/> Accessed: 01/05/2018

DAHL, Gordon B. Early Teen Marriage and Future Poverty. [online]. Available at: $<$ http://www.nber.org/papers/w11328.pdf> Accessed: 11/03/2018.

DOLEA, Carmen, ABOUZAHR, Carla. Global burden of obstructed labour in the year 2000. [online]. Available at: <http://cdrwww.who.int/healthinfo/statistics/ bod_obstructedlabour.pdf $>$ Accessed: 11/03/2018.

Early Marriage: Sexual Exploitation \& The Human Rights of Girls. The Forum on Marriage and the Rights of Women and Girls, 2001., pp. 9. Available at: <http:// www.crin.org/docs/resources/publications/1367EarlyMarriage.pdf> Accessed: $11 / 03 / 2018$.

GEIGER, Abigail, LIVINGSTON, Gretchen. 8 facts about love and marriage in America. [online]. Available at: <http://www.pewresearch.org/fact-tank/2018/02/13/8facts-about-love-and-marriage/> Accessed: 11/03/2018.

GIRLS NOT BRIDES. About Child Marriage. [online]. Available at: <https://www. girlsnotbrides.org/about-child-marriage/> Accessed: 11/03/2018.

GIRLS NOT BRIDES. Canada. [online]. Available at: <https://www.girlsnotbrides. org/child-marriage/canada/> Accessed: 19/04/2018.

GIRLS NOT BRIDES. India. [online]. Available at: <https://www.girlsnotbrides.org/ child-marriage/india/> Accessed: 11/03/2018.

GOVERNMENT OF CANADA. Child, early and forced marriage. [online]. Available 
at: <http://international.gc.ca/world-monde/issues_development-enjeux_developpement/human_rights-droits_homme/child_marriage-mariages_enfants. aspx?lang=eng $>$ Accessed: 19/04/2018.

International Covenant on Civil and Political Rights, art. 23, Dec. 16, 1966, 999 U.N.T.S. 171. [online]. Available at: <http://www.ohchr.org/Documents/ProfessionalInterest/ccpr.pdf> Accessed: 11/03/2018 (emphasis added).

INTERNATIONAL HUMANIST AND ETHICAL UNION. Child Marriage: A Violation of Human Rights. [online]. Available at: <http://iheu.org/child-marriageviolation-human-rights/> Accessed: 11/03/2018.

International Protecting Girls by Preventing Child Marriage Act of 2012, H.R. 6087, 112th Cong. (2012).

KIM, Shidug. Wedding Culture as a Traditional Ritual. [online]. Available at: <http:// ichcourier.ichcap.org/en/wedding-culture-as-a-traditional-ritual-2/> Accessed: $11 / 03 / 2018$.

KOLISETTY, Akhila. Child Marriage in India: Loopholes in the Law. [online]. Available at: <https://ilg2.org/2015/07/02/child-marriage-in-india-loopholes-in-thelaw/> Accessed: 11/03/2018

MOHAN, Rohini. Troubled Waters: Child Brides in Flood-ravaged Assam, India. [online]. Available at: <http://projects.aljazeera.com/2014/child-marriage/india. html> Accessed: 11/03/2018.

Office of the High Commissioner for Human Rights. Canadian efforts to address child, early and forced marriage. [online]. Available at: <www.ohchr.org/Documents/Issues/Women/WRGS/Earlyforcedmarriage/SG/Canada.docx > Accessed: 19/04/2018.

REISS, Fraidy. Why can 12-year-olds still get married in the United States? [online]. Available at: <https://www.washingtonpost.com/posteverything/wp/2017/02/10/ why-does-the-united-states-still-let-12-year-old-girls-get-married/?postshare $=7$ 01486850216167\&utm_term=.eb1a1dd94217> Accessed: 11/03/2018.

State Dep't of Human Res. v. Lott, 16 So. 3d 104 (2009 Ala.).

State v. Ward, 28 S.E.2d 785 (S.C. 1944).

STEWART, Terence P., SCHENEWERK, Caryn B. The Conflict Between Facilitating International Trade and Protecting U.S. Agriculture from Invasive Species: Aphis, The U.S. Plant Protection Laws, and the Argentine Citrus Dispute. Journal of Transnational Law and Policy, 2003, vol. 13, no. 2, pp. 305, 484. Available at: <http://www.law.fsu.edu/docs/default-source/journals/jtpl/previous-issues/ volume-13-number-2.pdf?sfvrsn=4> Accessed: 11/03/2018.

TERKEL, Amanda. House Republicans Block Child Marriage Prevention Act. [online]. Available at: <http://www.huffingtonpost.com/2010/12/17/house-republicansblock-child-marriage-prevention-act_n_798382.html> Accessed: 11/03/2018.

Unchained. [online]. Available at: <http://www.unchainedatlast.org > Accessed: 11/03/2018; SEILER, Naomi. Is Teen Marriage a Solution? [online]. Available at: <https://www.clasp.org/sites/default/files/public/resources-and-publications/ archive/0087.pdf. $>$ Accessed: 11/03/2018.

UNITED NATIONS CHILDREN'S FUND INNOCENTI RESEARCH CENTRE. Early Marriage: Child Spouses. Innocenti Digest, 2001, no. 7. Available at: $<\mathrm{htt}-$ ps://www.unicef-irc.org/publications/pdf/digest7e.pdf> Accessed: 11/03/2018. 
UNITED NATIONS POPULATION FUND. Obstetric fistula. [online]. Available at: $<$ https://www.unfpa.org/obstetric-fistula> Accessed: 11/03/2018.

Universal Declaration of Human Rights, 1948, art. 16. [online]. Available at: <http://www.ohchr.org/EN/UDHR/Documents/UDHR_Translations/eng.pdf.> Accessed: 11/03/2018

WANG, Wendy, PARKER, Kim. Chapter 1: Public Views on Marriage. [online]. Available at: <http://www.pewsocialtrends.org/2014/09/24/chapter-1-public-viewson-marriage/> Accessed: 11/03/2018

WARNER, Elizabeth. Behind the Wedding Veil: Child Marriage as a Form of Trafficking in Girls. Journal of Gender, Social Policy and Law, 2011, vol. 12, pp. 233, 247. Available at: <http://digitalcommons.wcl.american.edu/cgi/viewcontent. cgi? article $=1310 \&$ context=jgspl $>$ Accessed: $11 / 03 / 2018$.

WORLD POLICY ANALYSIS CENTER. Assessing National Action on Protection from Child Marriage. [online]. Available at: <https://www.worldpolicycenter.org/ sites/default/files/WORLD_Fact_Sheet_Legal_Protection_Against_Child_Marriage_2015.pdf> Accessed: 11/03/2018. 